\title{
Crecimiento de variedades y componentes del rendimiento de higuerilla (Ricinus communis L.) en Montecillo, Estado de México*
}

\author{
Growth of varieties and yield components of higuerilla \\ (Ricinus communis L.) in Montecillo, State of Mexico
}

\author{
José Luis Solís Bonilla ${ }^{1,2 \S}$, Abel Muñoz Orozco ${ }^{1}$, José Alberto Salvador Escalante Estrada ${ }^{1}$ A Alfredo Zamarripa Colmenero ${ }^{3}$ \\ ${ }^{1}$ Colegio de Postgraduados Campus Montecillo.Carretera México-Texcocokm36.5, Montecillo, Texcoco.C.P.56230,Estado de México.(amunozo@colpos.mx; jasee@ \\ colpos.mx). ${ }^{2}$ INIFAP-Campo Experimental Rosario Izapa.Carretera Tapachula-Cacahoatán km18. C.P.30870. Tuxtla Chico, Chiapas, México.(solis.joseluis@inifap.gob. \\ $\mathrm{mx}){ }^{3} \mathrm{RD} 2$ Visión, Camino a Calance S/N C. P. 30870, Tuxtla Chico, Chipas. (zamarripaco.alfre@yahoo.com.mx). ${ }^{\S}$ Autor para correspondencia: jose.solis@colpos.mx.
}

\section{Resumen}

Diversas instituciones se han encaminado a la búsqueda de nuevas fuentes de energía a partir de especies vegetales. Una de estas especies es la higuerilla (Ricinus communis L.), planta oleaginosa que se encuentra ampliamente distribuida en México. El objetivo de este trabajo fue estudiar la variabilidad y adaptación de un grupo de variedades de higuerilla en Montecillo, estado de México, localidad de clima templado. Se valoraron las variedades mediante un índice de selección y por componentes principales. El material genético consistió de 10 variedades mejoradas del INIFAP originarias de Chiapas y Michoacán y una no mejorada colectada en Montecillo. Se evaluaron características morfológicas, días a floración, y variables de racimos, frutos y semillas. De acuerdo a los índices de selección y componentes principales las variedades mejoradas V2 (Riric 265-1), V3 (Riric67-6) V6 (Riric19) y V10 (Riric1) fueron las de mejor adaptación y las características en las que más destacaron fueron diámetro de tallo, número de ramas, número de hojas, longitud del dosel, porte bajo y precocidad. La no mejorada sobresalió en longitud de racimo y frutos por racimo. Los índices de selección resultaron eficientes para precisar las mejores variedades y concordó con los agrupamientos determinados

\section{Abstract}

Several institutions have been directed to the search for new sources of energy from plants. One of these species is the higuerilla (Ricinus communis L.), oilseed plant that is widely distributed in Mexico. The aim of this work was to study the variability and customization of a group of varieties of higuerilla in Montecillo, State of Mexico, city of temperate climate. varieties were assessed by a selection index and major components. The genetic material consisted of 10 improved varieties of INIFAP originating in Chiapas and Michoacan and improved not collected at Montecillo. morphological, days to flowering, and variable clusters, fruits and seeds were evaluated. According to the selection indices and major components improved V2 (Riric 265-1), V3 (Riric67-6) V6 (Riric19) and V10 (Riric1) varieties were the best adaptation and characteristics which were highlighted more stem diameter, number of branches, number of leaves, length of the canopy, short stature and precocity. Improved it not excelled in length bunch and fruits per cluster. Selection indices were efficient to clarify the best varieties and agreed with the groups and conglomerates determined by major components. However, it presented severe frost, seed production which suggests the possibility of generating genetic material adapted to this altitudinal level was achieved.

\footnotetext{
* Recibido: diciembre de 2015

Aceptado: febrero de 2016
} 
porcomponentes principales y conglomerados. No obstante, de presentarse heladas severas, se logró la producción de semilla lo que sugiere la posibilidad de generar material genético adaptado a este nivel altitudinal.

Palabras claves: Ricinus communis L., adaptación, biocombustibles.

\section{Introducción}

Diversos países en el mundo han apoyado la utilización de especies productoras de biocombustibles con el objetivo de reducir las emisiones de gases de efecto invernadero (Zamarripa et al., 2012). Una de las alternativas es la higuerilla (Ricinus communis L.), especie oleaginosa que se encuentra ampliamente distribuida en México, y posee alto potencial de producción de semilla para la obtención de aceite. (Martínez et al., 2012). Más de 95\% de la producción de higuerilla en el mundo está concentrada en India, China y Brasil (Sailaja et al., 2008). India con 840,000 ha ${ }^{-1}$, cosechadas; China con 210,000 ha ${ }^{-1}$; Brasil con 159,205 ha ${ }^{-1}$ con una producción de grano de 1.09, 0.190 y 0.09 millones de $t$, respectivamente (FAOSTAT, 2011). El desarrollo del cultivo de higuerilla puede originar una cadena de nuevos negocios, tecnologías y productos (Mazzani, 1983; Brigham, 1993; Stachetti et al., 2007). Diversos autores mencionan que el desarrollo progresivo de los combustibles de la aviación y el empleo de motores de altas revoluciones, generan gran demanda de aceite de higuerilla, esto genera una necesidad de información técnica y científica sobre este cultivo en diversos nichos ecológicos (Tobar, 1981; Scholz y Da Silva, 2007; Sepúlveda, 2012).

La higuerilla es originaria de África, encontrándose en la República de Yemen al Norte de África, y en el Cercano y Medio Oriente (Purseglove, 1974; Vavilov, 1992). Es una planta de hábito anual o perenne de acuerdo a las condiciones ambientales (Vibrans, 2009), planta de dosel alto, a veces algo arbustiva, de color verde claro a grisáceo, en ocasiones rojiza, con tallo erecto de hasta $6 \mathrm{~m}$ de altura. (Rzedowski y Rzedowski, 2001). La semilla es ovalada, rara vez esférica o alargada, de 0.8 a $3 \mathrm{~cm}$ de longitud, 0.6 a $1.5 \mathrm{~cm}$ de ancho y 0.4 a $1.0 \mathrm{~cm}$ de espesor (Moshkin, 1986).

Presenta color variable con manchas rojizas y parduzcas, tiene una cubierta exterior dura y quebradiza y otra inferior muy fina de color blanquecino. Ambas protegen
Keywords: Ricinus communis L., adaptation, biofuels.

\section{Introduction}

Several countries in the world have supported the use of biofuels producing species in order to reduce emissions of greenhouse gases (Zamarripa et al., 2012). One alternative is the higuerilla (Ricinus communis L.), oilseed species that is widely distributed in Mexico, and has high potential for seed production to obtain oil (Martinez et al., 2012). More than $95 \%$ of the production of higuerilla in the world is concentrated in India, China and Brazil (Sailaja et al., 2008). India $840000 \mathrm{ha}^{-1}$, harvested; China $210000 \mathrm{ha}^{-1}$; Brazil $159205 \mathrm{ha}^{-1}$ with a grain yield 1.09, 0.190 and 0.09 million t respectively (FAOSTAT, 2011). The higuerilla crop development can cause a chain of new businesses, technologies and products (Mazzani, 1983, Brigham, 1993; Stachetti et al., 2007). Several authors mention that the progressive development of aviation fuels and the use of high-revving engines generate high demand for higuerilla oil, this creates a need for technical and scientific information on this crop in various ecological niches (Tobar, 1981; Scholz and Da Silva, 2007; Sepúlveda, 2012).

The higuerilla is native to Africa, being in the Republic of Yemen to North Africa, and the Near and Middle East (Purseglove, 1974, Vavilov, 1992). It is a plant annual or perennial habit according to environmental conditions (Vibrans, 2009), plant high canopy, sometimes a little shrub, from light to gray-green color, sometimes reddish, with erect stems up to $6 \mathrm{~m}$. (Rzedowski and Rzedowski, 2001). The seed is oval, spherical or elongated rarely, from 0.8 to $3 \mathrm{~cm}$ long, 0.6 to $1.5 \mathrm{~cm}$ wide and 0.4 to $1.0 \mathrm{~cm}$ thick (Moshkin, 1986).

Variable presented with reddish brownish stains and has a hard and brittle outer shell and a very fine whitish underside. Both protect the seed, which consists of a tiny embryo with two cotyledons thin and soft, compact and oily albumen (Weiss, 1983; Rzedowski and Rzedowski, 2001). The seed contains toxins such as ricin (which is an albumin belonging to the family of ribosome inactivating protein, they stop protein synthesis, causing cell death by apoptosis) and ricinina very toxic alkaloid that attack the liver and pancreas (Rzedowski and Rzedowski, 2001; Fanan et al., 2009). Higuerilla oil meets physicochemical characteristics that position it as an option on the production of biofuels 
la semilla, la cual consta de un embrión pequeño con sus dos cotiledones delgados y el albumen blando, compacto y aceitoso (Rzedowski y Rzedowski, 2001; Weiss, 1983). La semilla contiene toxinas como ricina (la cual es una albúmina perteneciente a la familia de proteínas desactivadoras de ribosomas, detienen la síntesis de proteínas, causando la muerte de las células por apoptosis) y la ricinina, alcaloide muy tóxico que atacan la hígado y al páncreas, (Rzedowski y Rzedowski, 2001; Fanan et al., 2009). El aceite de higuerilla reúne características fisicoquímicas que la posicionan como una opción en la producción de biocombustibles (Martínez et al., 2012). Además de su uso en la fabricación de surfactantes, revestimientos, grasas, fungistáticos, productos farmacéuticos, cosméticos y muchos otros productos (Lima et al., 2013).

Los estudios sobre los componentes del rendimiento proporcionan una orientación para lograr una producción óptima. Estos son interdependientes y cambian en respuesta a las condiciones ambientales. Las correlaciones negativas entre los componentes de rendimiento son muy frecuentes (Kumar et al., 1997; Rajala et al., 2009; Soratto et al., 2011, Sadras y Slafer, 2012). Algunos autores señalan que para la selección de variantes altamente productivas de higuerilla se debe hacer énfasis en el número de racimos y peso de fruto; así como en la longitud de los racimos y peso de semillas (Sarwar y Boota, 2008). En algunos estudios, el número de semillas por racimo se descompone en número de frutos por racimo y el número de semillas por fruto; sin embargo, estos dos componentes se analizan preferiblemente juntos porque hay una variación insignificante en el número de semillas por fruto (Fanan et al., 2009; Machado et al., 2009). El peso individual de las semillas juega un papel importante (Severino, 2012).

El peso de semilla está determinado por el potencial genético de la planta (Egli et al., 1987), pero la variabilidad en el peso de la semilla puede ser causada por muchos procesos fisiológicos que son sensibles a los cambios ambientales. En especies de polinización cruzada, el origen del embrión diploide y la naturaleza del endospermo triploide es una fuente potencial de variabilidad en el peso de la semilla (Hay et al., 2010). Por todo lo anterior, el objetivo del presente trabajo fue estudiar la variabilidad y adaptación de un grupo de variedades de higuerilla en Montecillo, Estado de México, de abril a diciembre de 2013.
(Martinez et al., 2012). Besides its use in the manufacture of surfactants, coatings, greases, fungistatic, pharmaceuticals, cosmetics and many other products (Lima et al., 2013).

Studies on yield components provide guidance for optimal production. These are interdependent and changein response to environmental conditions. Negative correlations between yield components are very common (Kumar et al., 1997; Rajala et al., 2009; Soratto et al., 2011, Sadras and Slafer, 2012). Some authors point out that for the selection of highly productive variants higuerilla emphasis should be placed on the number of clusters and fruit weight; as well as the length of the bunches and seed weight (Sarwar and Boota, 2008). In some studies, the number of seeds per cluster breaks down the number of fruits per cluster and the number of seeds per fruit; however, these two components are preferably analyzed together because there is negligible variation in the number of seeds per fruit (Fanan et al., 2009; Machado et al., 2009). Individual seed weight plays an important role (Severino, 2012).

Seed weight is determined by the genetic potential of the plant(Eglietal., 1987), but the variability in seed weight may be caused by many physiological processes that are sensitive to environmental changes. In cross-pollinated species, the origin of diploid embryo and endosperm triploid nature is a potential variability in seed weight (Hay et al., 2010) source. Given the above, the objective of this work was to study the variability and adaptation of a group of varieties of higuerilla in Montecillo, State of Mexico, from April to December 2013.

\section{Materials and methods}

The experiment was conducted in the period from april to december 2013 in the experimental field of the Graduate College, located in Montecillo, Texcoco, State of Mexico, with geographic coordinates $19^{\circ} 28^{\prime} 02.9^{\prime \prime}$ north latitude and $98^{\circ} 54^{\prime} 02.3^{\prime \prime}$ west longitude and an altitude of 2 240 meters. The climate according to Koppen climate classification modified by García (2005) is C (Wo) (W) b (i'), corresponding to temperate humid with summer rains. The average annual rainfall and temperature are $625 \mathrm{~mm}$ and 16 ${ }^{\circ} \mathrm{C}$ respectively. Precipitation of the year into the experiment in april and lasted to mid-october with a bimodal regime with 


\section{Materiales y métodos}

El experimento se desarrolló en el periodo abril-diciembre de 2013 en el Campo Experimental del Colegio de Postgraduados, localizado en Montecillo, Texcoco, Estado de México, con coordenadas geográficas $19^{\circ}$ $28^{\prime} 02.9$ " de latitud norte y $98^{\circ}$ 54'02.3" de longitud oeste y una altitud de $2240 \mathrm{msnm}$. El clima de acuerdo a la clasificación climática de Köppen modificada por García (2005) es C (Wo) (W) b (i'), correspondiente al clima templado subhúmedo con lluvias en verano. La precipitación y la temperatura media anual son de 625 mm y $16{ }^{\circ} \mathrm{C}$ respectivamente. La precipitación del año del experimento inicio en abril y duró a mediados de octubre con un régimen bimodal, con sequia intraestival (SI) en el mes de agosto y la gran sequía invernal (GSI) de mediados de octubre hasta mediados de marzo. La precipitación acumulada durante la estación de crecimiento del cultivo fue de $639 \mathrm{~mm}$ (Figura 1). Se presentaron heladas de inicios de diciembre a mediados de febrero (Figura 2). Los datos de las variables meteorológicas se obtuvieron de las estaciones ubicadas en el Colegio de Postgraduados y de la Universidad Autónoma Chapingo. intraestival drought (SI) in the month of august and the great winter drought (GSI) in mid-october to mid-march. The cumulative rainfall during the crop growing season was 639 $\mathrm{mm}$ (Figure 1). frost early december to mid-february (Figure 2 ) were presented. The data of meteorological variables were obtained from the stations in the Graduate College and the University of Chapingo.

The soil of the Experimental Station (Table 1) was analyzed, it is a sandy loam, moderately basic and slightly saline soil, with percentages of organic matter (M.O.) of $2-3 \%$

Was evaluated 11 varieties of higuerilla: 10 improved and CP13 collection "unimproved" (Table 2). The INIFAP varieties were selected according to previous results obtained by Zamarripa et al. (2010). seed collected was used in 2013 in the Graduate College in Montecillo in unimproved. The experiment was established on April 6, 2013. The experimental plot was 6 meters long and 1.5 meters wide $(9 \mathrm{~m} 2)$, with five plants per row, in square 1.5 x $1.5 \mathrm{~m}$. The population density was 4444 plants $_{\text {ha }}{ }^{-1}$. The five plants formed the useful plot. design used randomized block with four replications. In those variables that readings

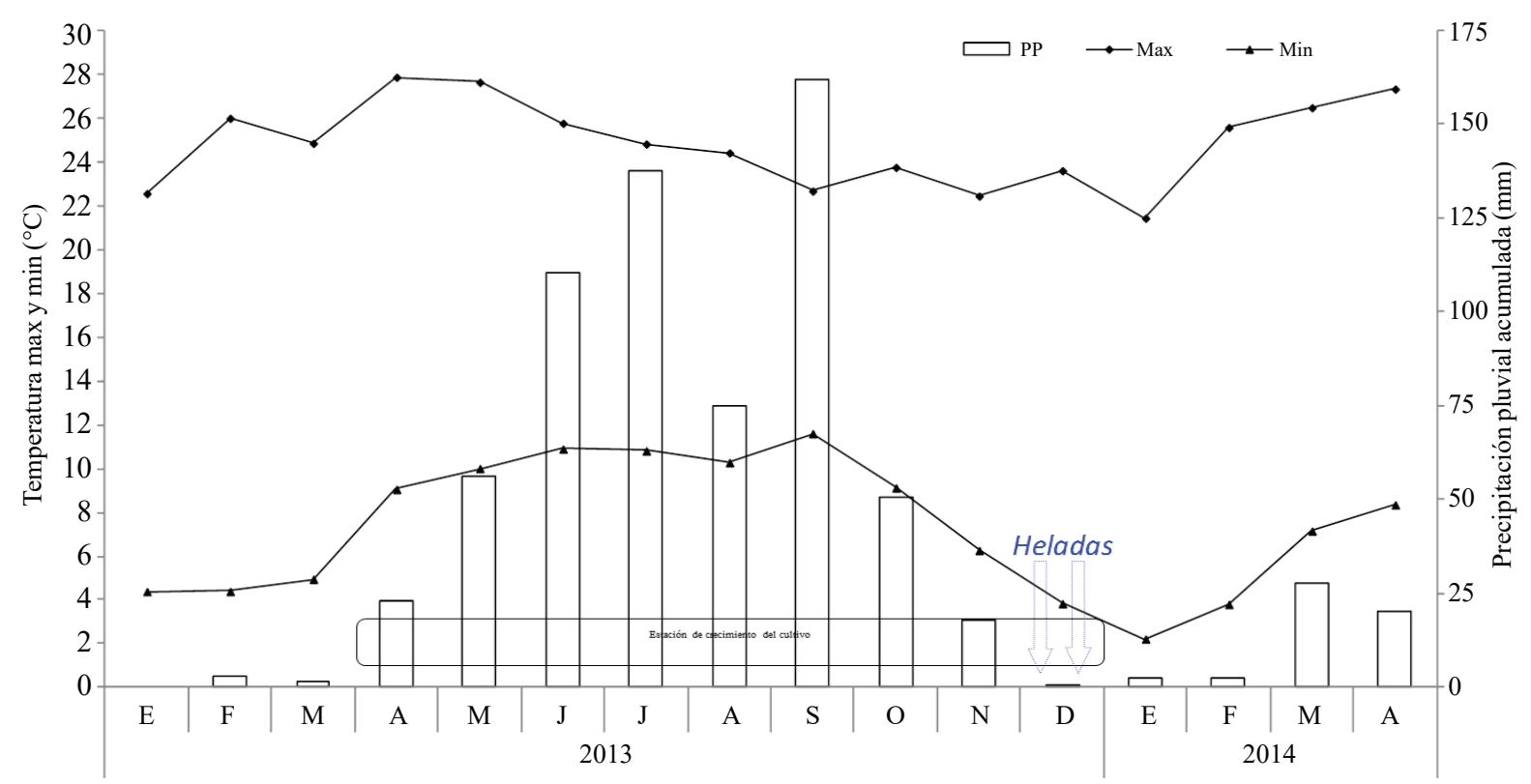

Figura 1. Precipitación pluvial durante la estación de crecimiento del cultivo en Montecillo, ciclo abril-diciembre de 2013. Figure 1. Rainfall during the growing season of the crop in Montecillo, cycle from april to december 2013. 


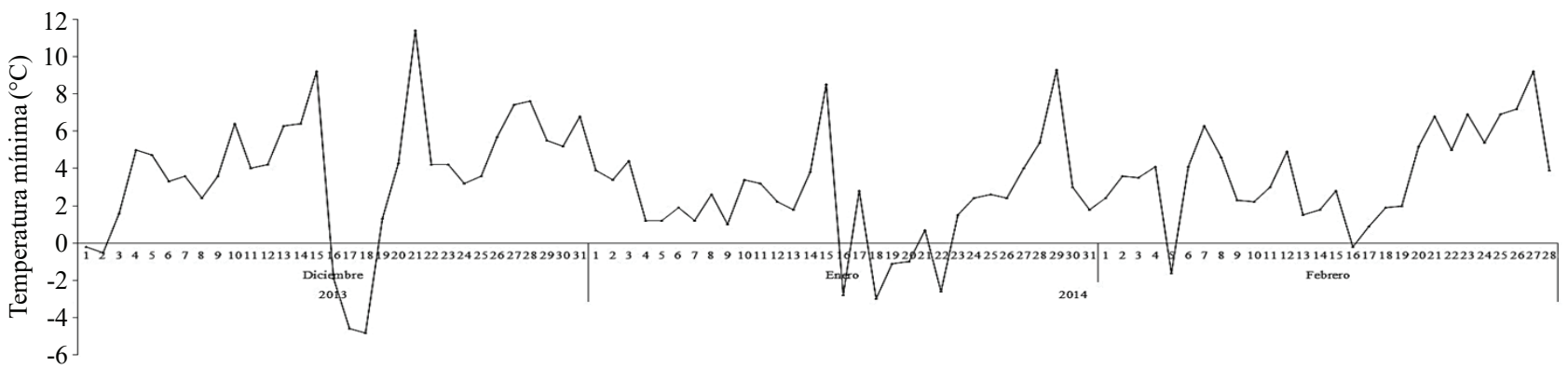

Figura 2. Temperaturas mínimas diarias al final del ciclo del cultivo en Montecillo, ciclo abril-diciembre de 2013. Figure 2. Minimum daily at the end of the crop cycle in Montecillo, cycle from april to december 2013 temperatures.

Se analizó el suelo del Campo Experimental (Cuadro 1), se trata de un suelo franco arenoso, moderadamente básico y ligeramente salino, con porcentajes de materia orgánica (M.O.) de 2 a $3 \%$ on several dates were conducted it generated a factorial design with two factors, varieties and readings under a split plot arrangement where readings were for large plots and subplots varieties. The model is as follows:

Cuadro 1. Principales propiedades del suelo del lote experimental en Montecillo.

Table 1. Main properties of the soil of the experimental batch Montecillo.

\begin{tabular}{|c|c|c|c|c|c|c|c|c|c|c|}
\hline Textura & $\mathrm{pH}$ & $\begin{array}{c}\mathrm{CE} \\
\mathrm{dS} \mathrm{m}^{-1}\end{array}$ & $\begin{array}{c}\mathrm{CIC} \\
\mathrm{meq} / 100 \mathrm{~g}\end{array}$ & $\begin{array}{l}\mathrm{MO} \\
(\%)\end{array}$ & $\begin{array}{c}\mathrm{N} \text { total } \\
(\%)\end{array}$ & $\begin{array}{c}\mathrm{P} \\
\mathrm{mg} \mathrm{kg}^{-1}\end{array}$ & $\mathrm{~K}$ & $\begin{array}{l}\mathrm{Ca} \\
\mathrm{cmo}\end{array}$ & $\mathrm{Mg}$ & $\mathrm{Na}$ \\
\hline Franco arenoso & 7.9 & 0.77 & 27.5 & 2.98 & 0.15 & 13.15 & 1.56 & 27.35 & 17.5 & 0.71 \\
\hline
\end{tabular}

Se evaluaron 11 variedades de higuerilla: 10 mejoradas y la colecta CP13 "no mejorada" (Cuadro 2). Las variedades del INIFAP fueron seleccionados de acuerdo a resultados previos obtenidos por Zamarripa et al. (2010). En la no mejorada, se utilizó semilla colectada en el año 2013 en el Colegio de Postgraduados en Montecillo. El experimento se estableció el 6 de abril de 2013. La parcela experimental fue de 6 metros de largo por 1.5 metros de ancho $\left(9 \mathrm{~m}^{2}\right)$, con cinco plantas por surco, en cuadrado a $1.5 \times 1.5 \mathrm{~m}$. La densidad de población fue de 4444 plantas ha $^{-1}$. Las cinco plantas formaron la parcela útil. Se usó un diseño de bloques al azar, con cuatro repeticiones. En aquellas variables en que se realizaron lecturas en varias fechas se generó un diseño factorial con dos factores, variedades y lecturas, bajo un arreglo de parcelas divididas en donde las lecturas correspondieron a las parcelas grandes y las variedades las subparcelas. El modelo es el siguiente:

$\mathrm{Y}=\mathrm{Rep}+\mathrm{Lec}+$ Error $\mathrm{a}+\operatorname{Var}+\operatorname{Var} \mathrm{x}$ Lec + Error $\mathrm{b}$

Donde: $\mathrm{Y}=$ variación total de la variable respuesta; $\mathrm{Rep}=$ variación de repeticiones; $\mathrm{Lec}=$ variación de lecturas; error $\mathrm{a}=$ variación asociada a parcelas grandes; Var $=$ variación de las variedades; Var $\mathrm{x} \mathrm{Lec}=$ interacción de variedades por lecturas; error $b=$ variación asociada a subparcelas.
$\mathrm{Y}=$ Rep + Lec + Error $\mathrm{a}+\operatorname{Var}+\operatorname{Var} \mathrm{x}$ Lec + Error $b$

Where: $Y=$ total variation of the response variable; Rep= variation of repetitions; $L e c=$ change in lectures; error= variation associated with large plots; Var $=$ variation of the varieties; Var $\mathrm{x}=$ interaction Lec varieties readings; Error $\mathrm{b}=$ variation associated with subplots.

The variables evaluated with more than one reading date were: plant height (AP) measured from the ground surface to the upper end, stem diameter (DT) $40 \mathrm{~cm}$ above the ground, leaf number $(\mathrm{NH})$ counted from the base of the stem to the high end, number of branches (NR) of the base of the stem to the first fork, plant canopy area (ABS) for this width (ADS) and took over (LDS) canopy.

The variables are recorded once a day to flowering (DF), number of clusters perplant(NRP), cluster length(LR), number of fruits per bunch (NF), equatorial diameter (OD) and polar (DP) of fruit and fruit weight (PF). Likewise characteristics were measured in seed: length (LS), width (AS), thickness (GS), volume(VL), length/width ratio(RLA), 100 seed weight (PCS) and seed production(REN). The model for the analysis of these variables experiment corresponded toa simpleblocks, and errorvarieties as variation factors as described immediately. 
Cuadro 2. Origen de las variedades de higuerilla utilizadas en el estudio de variabilidad y adaptación en Montecillo Table 2. Origin of higuerilla varieties used in the study of variability and adaptation in Montecillo.

\begin{tabular}{lclcc}
\hline \multicolumn{1}{c}{ Genotipo } & Forma & \multicolumn{1}{c}{ Origen } & Altitud (msnm) & Color de semilla \\
\hline Riric269-3 & M & Morelia, Michoacán & 1695 & Café veteado \\
Riric265-1 & M & Barranca Honda, Michoacán & 872 & Crema veteado \\
Riric67-6 & M & Frontera Comalapa, Chiapas & 687 & Crema veteado \\
Riric267-2 & M & Tipitio, Uruapan, Michoacán & 2101 & Crema veteado \\
Riric10 & M & Unión Juárez, Chiapas & 878 & Crema veteado \\
Riric19 & M & Sierra Morena, Villa Corzo, Chiapas & 1070 & Crema veteado \\
Riric29 & M & La Garza, Villaflores, Chiapas & 605 & Café veteado \\
Riric274 & M & San Jerónimo,Unión Juárez, Chiapas & 776 & Crema veteado \\
Riric273 & $\mathrm{M}$ & Guatimoc, Cacahoatán, Chiapas & 809 & Crema veteado \\
Riric1 & $\mathrm{M}$ & Unión Roja, Cacahoatán, Chiapas & 519 & Café veteado \\
CP13 & $\mathrm{NM}$ & Montecillo, Texcoco, Edo. de México & 2240 & Gris veteado \\
\hline
\end{tabular}

M; mejorado, NM; no mejorado.

Las variables evaluadas con más de una fecha de lectura fueron: altura de la planta (AP) medida desde la superficie del suelo hasta el extremo más alto, diámetro de tallo(DT) $40 \mathrm{~cm}$ arriba del suelo, número de hojas $(\mathrm{NH})$ contadas a partir de la base del tallo hasta el extremo más alto, número deramas(NR)dela base del tallohasta la primera bifurcación, áreadel dosel vegetal (ABS): paraellosetomóelancho(ADS)y largo(LDS)deldosel.

Las variables que se registraron una vez corresponden a los días a floración(DF),númerode racimos porplanta(NRP), longitud del racimo (LR), número de frutos por racimo (NF), diámetro ecuatorial (DE) y polar (DP) de fruto y peso de fruto (PF). Así mismo se midieron características en semilla: longitud (LS), ancho(AS), grosor(GS), volumen(VL), relación largo/ancho (RLA), peso de 100 semillas (PCS) así como la producción de semilla (REN). El modelo para el análisis de estas variables correspondió a un experimento simple conbloques, variedades y error como factores de variación según se indica en seguida.

$\mathrm{Y}=\mathrm{Rep}+\operatorname{Var}+$ Error

Donde: $\mathrm{Y}=$ variación total de la variable respuesta; rep= variación de repeticiones; $v a r=$ variación de las variedades; error= variación asociada al error.

Los análisis se hicieron a través del programa estadístico SAS 9.0 (SAS Insitute Inc., Cary, NC, USA) y las medias comparadas por la prueba de Duncan, con un nivel de
$\mathrm{Y}=\mathrm{Rep}+\operatorname{Var}+$ Error

Where: $\mathrm{Y}=$ total variation of the response variable; rep= variation of repetitions; var $=$ change in varieties; error $=$ variation associated with the error.

The analyzes were performed using the statistical program SAS 9.0 (SAS Insitute Inc., Cary, NC, USA) and the averages compared by Duncan test, with a significance level of 5\%. To develop a selection index (IS), which involve all response variables were assigned a "1" for each "a" in the line of each variety. The sum of "1" was the IS. Thus the index integrates the adaptive effect of all the features that the variety showed good response in the environment of Montecillo. Finally stockings varieties of all variables in the study were subjected to multivariate analysis of main components.

\section{Results and discussion}

\section{Factor analysis with dates and varieties}

The significance was detected in blocks, dates of lectures and seven varieties of plant characteristics evaluated, the varieties reading dates interaction was significant only for plant height (Table 3). 
significación del 5\%. Para elaborar un índice de selección (IS), en que intervengan todas las variables de respuesta se asignó un " 1 " por cada "a" en el renglón de cada variedad. La suma de los "1" constituyó el IS. Así el índice integra el efecto adaptativo de todas las características en que la variedad mostró buena respuesta en el ambiente de Montecillo. Finalmente las medias de variedades de todas las variables en estudio fueron sometidas a análisis multivariados de componentes principales.

\section{Resultados y discusión}

\section{Análisis factorial con fechas y variedades}

Se detectó significancia en bloques, fechas de lecturas y variedades en siete características de planta evaluadas, la interacción variedades por fechas de lectura fue significativa solo para altura de planta (Cuadro 3).

\section{Morphological variation among plant varieties}

This variation is illustrated in Table 4, in the column of each variable varieties with the letter "a" are statistically equal and higher. According to the IS, the varieties 1 (Riric269-3) mode 6; 3 (Riric67-6) and 4 (Ricirc267-2) with values of 5, were the best index. They marked in bold the most important characteristics in each variety, allowing appreciate the frequency characteristic. The characteristics most frequently were the DT, NR, NH, LDS reflecting the features of greater emphasis on the selection. In relation to the AP, the low frequency of high plants improved varieties it indicates that the selection has focused on plants reduced height.

\section{Characteristics of clusters and fruit}

The analysis of variance is summarized in Table 5, there was significance in the variables repeats fruit bunches (FR) and polar fruit diameter(DP). For six varieties significance

Cuadro 3. Relaciones entre fuentes de variación y características morfológicas de planta en Montecillo; cuadrados medios y significancia, ciclo abril-diciembre de 2103.

Table 3. Relations between sources of variation and morphological characteristics of plant Montecillo; square means and significance, from April to December 2103 cycle.

\begin{tabular}{ccccccccc}
\hline FV & GL & AP & DT & NR & NH & ADS & LDS & ABS \\
\hline Bloques & 3 & $13972.2^{* *}$ & $15.3^{* *}$ & $8.83^{* *}$ & $64.82^{* *}$ & $25164.3^{* *}$ & $29237.1^{* *}$ & $2.6^{* *}$ \\
Fechas & 9 & $407383.0^{* *}$ & $388.4^{* *}$ & $30.6^{* *}$ & $735.2^{* *}$ & $694667.7^{* *}$ & $652741.5^{* *}$ & $66.9^{* *}$ \\
Error a & 27 & 637.6 & 0.61 & 0.23 & 3.17 & 1530.3 & 1446.1 & 0.13 \\
Variedades & 10 & $4849.1^{* *}$ & $7.7^{* *}$ & $2.41^{* *}$ & $17.18^{* *}$ & $8699.5^{* *}$ & $9295.7^{* *}$ & $0.81^{* *}$ \\
Var x fech & 90 & $516.9^{* *}$ & $0.58 \mathrm{~ns}$ & $0.15 \mathrm{~ns}$ & $1.30 \mathrm{~ns}$ & $942.5 \mathrm{~ns}$ & $516.1 \mathrm{~ns}$ & $0.04 \mathrm{~ns}$ \\
Error b & 169 & 192.7 & 0.35 & 0.10 & 1.43 & 1124.1 & 1083.7 & 0.09 \\
CV & & 16.65 & 20.86 & 16.17 & 22.77 & 27.62 & 20.91 & 22.61 \\
$\mathrm{R}^{2}$ & & 0.98 & 0.96 & 0.85 & 0.93 & 0.93 & 0.96 & 0.95 \\
\hline
\end{tabular}

$\mathrm{FV}=$ fuente de variación; $\mathrm{GL}=$ grados de libertad; $\mathrm{AP}=$ altura de planta; $\mathrm{DT}=$ diámetro de tallo; $\mathrm{NR}=$ número de ramas; $\mathrm{NH}=$ número de hojas; $\mathrm{ADS}=$ ancho del dosel; LDS $=$ longitud del dosel; ABS= área basal ${ }^{*}$ *Diferencias significativas a 0.01 de probabilidad; $*$ Diferencias significativas a 0.05 de probabilidad; ns $=$ no significativo.

\section{Variación de características morfológicas de planta entre variedades}

Esta variación se ilustra en el Cuadro 4, en la columna de cada variable las variedades con la letra "a" son las estadísticamente iguales y superiores. Acorde al IS, las variedades 1(Riric269-3) con valor 6; 3(Riric67-6) y 4(Ricirc267-2) con valores de 5, fueron las de mejor índice. Se marcaron en negritas las características más destacadas en cada variedad, lo que permite apreciar la frecuencia por característica. Las características con mayor frecuencia fueron elDT, NR, NH, LDS lo que refleja los rasgos de mayor was detected characteristics, and was not observed for the number of clusters per plant (NRP). As for days to flowering there was significance in repetitions and varieties.

\section{Variation of the characteristics of clusters and fruits and selection index between varieties}

Improved varieties (1-10) have increased the unimproved NRP (CP13), however this is longer cluster and number of fruits per cluster, features that can be useful in crosses or reciprocal recurrent selection schemes. As in the previous case the selection index was developed; in the case of the 
énfasis en la selección. En relación a la AP, la baja frecuencia de plantas altas en las variedades mejoradas indica que la selección se ha orientado a plantas de altura reducidas. variable days to flowering by the interest in early varieties are those with letter"c" is assigned"1". The varieties with the best index were the two (Riric265-1), 5 (Riric10), 6 (Riric19) and

Cuadro 4. Comparación de medias de las características morfológicas de planta e índice de selección de las variedades de higuerilla en Montecillo, ciclo abril-diciembre de 2013.

Table 4. Comparison of means of morphological and plant selection index higuerilla varieties in Montecillo, cycle from April to December of 2013 features.

\begin{tabular}{|c|c|c|c|c|c|c|c|c|}
\hline Variedades & $\mathrm{AP}(\mathrm{cm})$ & $\mathrm{DT}(\mathrm{cm})$ & NR & $\mathrm{NH}$ & ADS (cm) & LDS (cm) & $\operatorname{ABS}\left(\mathrm{m}^{2}\right)$ & IS \\
\hline 1 & $101.4 \mathrm{~b}$ & $3.7 \underline{\mathrm{a}}$ & $12.4 \underline{\mathrm{a}}$ & $57.4 \mathrm{ab}$ & $167.8 \underline{\mathrm{a}}$ & $158.1 \mathrm{a}$ & $3.9 \mathrm{a}$ & 6 \\
\hline 2 & 85.7 cde & $3.5 \underline{\mathrm{ab}}$ & $10.8 \underline{\mathrm{a}} \mathrm{b} \mathrm{c}$ & 45.9 abcde & $144.7 \mathrm{bc}$ & $144.4 \underline{\mathrm{a}} \mathrm{b}$ & $3.1 \mathrm{bc}$ & 4 \\
\hline 3 & $90.9 \mathrm{~cd}$ & $3.7 \underline{\mathrm{a}}$ & $10.7 \underline{a} \mathrm{bc}$ & 46.1 abcde & $142.9 \mathrm{bcd}$ & $152.0 \underline{\mathrm{a}} \mathrm{b}$ & $3.4 \underline{a b}$ & 5 \\
\hline 4 & 89.0 cde & $3.5 \underline{\mathrm{a}} \mathrm{b}$ & $12.2 \underline{\mathrm{ab}}$ & $62.8 \underline{\mathrm{a}}$ & $120.9 \mathrm{def}$ & $147.9 \underline{\mathrm{a} b}$ & $3.4 \mathrm{ab}$ & 5 \\
\hline 5 & $87.2 \mathrm{cde}$ & $3.0 \mathrm{~cd}$ & $9.8 \overline{b c}$ & $39.7 \overline{\mathrm{e}}$ & $88.7 \mathrm{~g}$ & $136.6 \bar{b}$ & $2.5 \mathrm{c}$ & 0 \\
\hline 6 & $88.6 \mathrm{cde}$ & $3.4 \underline{\mathrm{ab}}$ & $10.6 \underline{a b}$ & $53.4 \underline{\mathrm{abc}}$ & $149.8 \underline{\mathrm{ab}}$ & $138.4 \mathrm{~b}$ & $3.0 \mathrm{bc}$ & 4 \\
\hline 7 & $93.3 \mathrm{c}$ & $3.0 \mathrm{~d}$ & $11.4 \underline{\mathrm{a} b}$ & $49.6 \underline{\mathrm{a}} \mathrm{bcd}$ & $121.7 \mathrm{cdef}$ & $148.4 \underline{\mathrm{a} b}$ & $3.0 \mathrm{bc}$ & 3 \\
\hline 8 & $110.8 \underline{\mathrm{a}}$ & $3.3 \mathrm{abc}$ & $10.0 \mathrm{bc}$ & $40.2 \mathrm{de}$ & $142.7 \mathrm{bcd}$ & $144.0 \mathrm{ab}$ & $3.0 \mathrm{bc}$ & 3 \\
\hline 9 & $81.1 \mathrm{e}$ & $3.2 \mathrm{bcd}$ & $12.1 \underline{a b}$ & $55.4 \underline{\mathrm{a}} \mathrm{b}$ & $110.0 \mathrm{f}$ & $153.1 \underline{\mathrm{a}} \mathrm{b}$ & $3.4 \underline{\mathrm{ab}}$ & 4 \\
\hline 10 & $84.8 \mathrm{de}$ & $3.4 \mathrm{abc}$ & $8.6 \mathrm{c}$ & 45.4 cde & 136.0 bcde & $142.0 \underline{\mathrm{ab}}$ & $3.2 \mathrm{bc}$ & 2 \\
\hline 11 & $68.4 \mathrm{f}$ & $2.3 \mathrm{e}$ & $6.3 \mathrm{~d}$ & $26.3 \mathrm{f}$ & 118.0 ef & $104.0 \mathrm{c}$ & $2.1 \mathrm{~d}$ & 0 \\
\hline Media & 89.24 & 3.33 & 10.49 & 47.50 & 131.23 & 142.69 & 3.14 & \\
\hline${ }^{+}$Frec-pc & 1 & 7 & 7 & 7 & 2 & 8 & 4 & \\
\hline
\end{tabular}

$\mathrm{AP}=$ altura de planta; $\mathrm{DT}=$ diámetro de tallo; $\mathrm{NR}=$ número de ramas; $\mathrm{NH}=$ número de hojas; $\mathrm{ADS}=$ ancho del dosel; $\mathrm{LDS}=$ longitud del dosel; $\mathrm{ABS}=$ área basal $\left(\mathrm{m}^{2}\right) ; \mathrm{IS}=$ índice de selección o frecuencia de "aes" por variedad, ${ }^{+}$frecuencia de "aes" por característica. Promedios con la misma letra dentro de columnas son estadísticamente iguales según la prueba de Duncan $(p \leq 0.05)$.

\section{Características de racimos y frutos}

El análisis de variación se sintetiza en el Cuadro 5, hubo significancia en repeticiones en las variables frutos por racimos (FR) y diámetro polar de fruto(DP). Para variedades se detectó significancia para seis características, y no se observó para el número de racimos por planta (NRP). En cuanto a días a floración hubo significancia en repeticiones y variedades.
10 (Riric1) with values of 5 (Table 6). They stood by characteristics of large and heavy fruit traits that have been influenced by the selection process. Another character most often in improved varieties was thenumber of clusters perplant.

Barriosetal.(2013)mention that the average numberof clusters in Morelos was 11. For his part Machado et al. (2009)reported from 34 to 143 fruits per cluster. Similar results were found in this investigation. Barrios etal. (2013) found Morelos ranges

Cuadro 5. Relaciones entre fuentes de variación y características de racimos y frutos en Montecillo; cuadrados medios y significancia, ciclo abril-diciembre de 2013.

Table 5. Relations between sources of variation and characteristics of fruit bunches and Montecillo; square means and significance, from april to december of 2013 cycle.

\begin{tabular}{ccccccccc}
\hline FV & GL & DF & NRP & LR & FR & DP & DE & PF \\
\hline Repeticiones & 3 & $734.6^{* *}$ & $2.372 \mathrm{~ns}$ & $25.61 \mathrm{~ns}$ & $182.46^{*}$ & $0.09^{*}$ & $0.06 \mathrm{~ns}$ & $1.89 \mathrm{~ns}$ \\
Variedades & 10 & $832.1^{* *}$ & $2.25 \mathrm{~ns}$ & $699.17^{* *}$ & $3051.40^{* *}$ & $0.78^{* *}$ & $0.91^{* *}$ & $57.11^{* *}$ \\
CV & & 9.62 & 28.10 & 13.04 & 20.59 & 6.00 & 6.22 & 17.68 \\
$\mathrm{R}^{2}$ & & 0.81 & 0.60 & 0.93 & 0.93 & 0.85 & 0.86 & 0.79 \\
\hline
\end{tabular}

$\mathrm{FV}=$ fuente de variación; $\mathrm{GL}=$ grados de libertad, $\mathrm{DF}=$ días a floración; $\mathrm{NRP}=$ número de racimos por planta; $\mathrm{LR}=$ longitud de racimo; $\mathrm{FR}=$ frutos por racimo; $\mathrm{DP}=$ diámetro polar de fruto; $\mathrm{DE}=$ diámetro ecuatorial de fruto; $\mathrm{PF}=$ peso de fruto. ${ }^{*}$ Diferencias significativas a 0.01 de probabilidad, $*$ diferencias significativas a 0.05 de probabilidad $\mathrm{ns}=$ no significativo. 
Variación de las características de racimos y frutos e índice de selección entre variedades

Las variedades mejoradas ( 1 a 10) presentan mayor NRP que la no mejorada (CP13), en cambio esta tiene mayor longitud de racimo y número de frutos por racimo, características que pueden ser útiles en cruzamientos o en esquemas de selección reciproca recurrente. Como en el caso anterior se elaboró el índice de selección; en el caso particular de la variable días a floración por el interés en las variedades precoces que son las que tienen letra "c" se les asignó el " 1 ". Las variedades con el mejor índice fueron la 2(Riric265-1), 5(Riric10), 6(Riric19) y 10(Riric1) con valores de 5 (Cuadro 6). Sobresalieron por características de fruto grande y pesado, rasgos que se han influenciado por el proceso de selección. Otro carácter con mayor frecuencia en las variedades mejoradas fue el número de racimos por planta.

Barrios et al.(2013) mencionan que el promedio del número de racimos en Morelos fue de 11. Por su parte Machado et al. (2009) reportaron de 34 a 143 frutos por racimo. Resultados similares se encontraron en esta investigación. Barrios et al. (2013) en Morelos encontraron rangos de días a floración de 40 a 72 dds. En esta investigación los rangos de DF fluctuaron de 99 a 149 dds, las diferencias residen en el nivel altitudinal y clima, siendo Morelos de clima más cálido y seco. from days to flowering 40-72 dds. This research ranges DF ranged from $99-149 \mathrm{dds}$, the differences lie in the altitudinal level and climate, being Morelos warmer and drier climate.

\section{Seed characteristics}

Forvarieties significance to the seven characteristics of seeds evaluated (Table 7) was detected. There were significant variables repetitions in seed volume (VL) and weight of 100 seeds (PCS).

\section{Variation of the characteristics of seed and selection index between varieties}

The varieties 5(Riric10), 6 (Riric19) and 10 (Riric1) were the best selection index values 6 (Table 8 ). The results for the variable weight of 100 seeds show an amplitude in the means obtained for varieties which gives an idea of the variability between these grown materials. This same variability was observed in Morelos by Barrios et al. (2013). Likewise, Mazzani (1983) reports similar results to the research in Maracay, Venezuela found 100 seed weight between 19 and $91.8 \mathrm{~g}$.

The varieties had the highest frequencies in the selection indices: V6 (Riric19), V2 (Riric 265-1) and V10 (Riric1) conglomerated in the ACP group III with the difference that in the main components variables are confused and indices are explicit(Figure 3).

Cuadro 6. Comparación de medias de las características de racimos y frutos e IS de las variedades de higuerilla en Montecillo, ciclo abril-diciembre de 2013.

Table 6. Comparison of means of the characteristics of clusters and fruit and IS higuerilla varieties in Montecillo, cycle from april to december 2013.

\begin{tabular}{ccccccccc}
\hline Variedades & DF $(\mathrm{dds})$ & NRP & LR $(\mathrm{cm})$ & FR & DP $(\mathrm{cm})$ & DE $(\mathrm{cm})$ & PF $(\mathrm{g})$ & IS \\
\hline 1 & $122 \mathrm{~b}$ & $31.6 \underline{\mathrm{a}} \mathrm{b}$ & $44.2 \mathrm{~b}$ & $62.2 \mathrm{~b}$ & $2.4 \mathrm{~d}$ & $2.4 \mathrm{c}$ & $6.0 \mathrm{c}$ & 1 \\
2 & $108 \mathrm{~b} \underline{\mathrm{c}}$ & $29.1 \underline{\mathrm{a}}$ & $16.9 \mathrm{e}$ & $18.1 \mathrm{e}$ & $3.0 \underline{\mathrm{a}}$ & $3.2 \underline{\mathrm{a}}$ & $13.2 \underline{\mathrm{a}}$ & 5 \\
3 & $111 \mathrm{~b} \underline{\mathrm{c}}$ & $29.0 \underline{\mathrm{a} b}$ & $20.4 \mathrm{cde}$ & $23.2 \mathrm{de}$ & $2.9 \mathrm{bc}$ & $3.1 \underline{\mathrm{a}}$ & $11.6 \underline{\mathrm{a}}$ & 4 \\
4 & $122 \mathrm{~b}$ & $32.2 \underline{\mathrm{a}} \mathrm{b}$ & $23.4 \mathrm{~cd}$ & $30.7 \mathrm{~cd}$ & $2.9 \mathrm{bc}$ & $3.0 \underline{\mathrm{a}}$ & $11.8 \underline{\mathrm{a}}$ & 3 \\
5 & $117 \mathrm{~b} \underline{\mathrm{c}}$ & $28.0 \underline{\mathrm{a}} \mathrm{b}$ & $18.4 \mathrm{de}$ & $24.5 \mathrm{cde}$ & $3.2 \underline{\mathrm{a}}$ & $3.2 \underline{\mathrm{a}}$ & $13.6 \underline{\mathrm{a}}$ & 5 \\
6 & $99 \underline{\mathrm{c}}$ & $29.0 \underline{\mathrm{a}} \mathrm{b}$ & $18.4 \mathrm{de}$ & $24.6 \mathrm{cde}$ & $3.1 \underline{\mathrm{a}}$ & $3.2 \underline{\mathrm{a}}$ & $12.8 \underline{\mathrm{a}}$ & 5 \\
7 & $104 \underline{\mathrm{c}}$ & $24.5 \underline{\mathrm{a}} \mathrm{b}$ & $24.9 \mathrm{c}$ & $31.0 \mathrm{~cd}$ & $2.7 \mathrm{c}$ & $2.7 \underline{\mathrm{b}}$ & $8.9 \mathrm{~b}$ & 2 \\
8 & $103 \underline{\mathrm{c}}$ & $40.3 \underline{\mathrm{a}}$ & $16.6 \mathrm{e}$ & $25.0 \mathrm{cde}$ & $2.9 \mathrm{bc}$ & $3.0 \underline{\mathrm{a}}$ & $10.7 \underline{\mathrm{a}} \mathrm{b}$ & 4 \\
9 & $100 \underline{\mathrm{c}}$ & $27.5 \underline{\mathrm{ab}}$ & $21.7 \mathrm{cde}$ & $36.0 \mathrm{c}$ & $2.3 \mathrm{~d}$ & $2.4 \mathrm{c}$ & $5.5 \mathrm{c}$ & 2 \\
10 & $104 \underline{\mathrm{c}}$ & $35.0 \underline{\mathrm{a}} \mathrm{b}$ & $18.9 \mathrm{de}$ & $25.8 \mathrm{cde}$ & $3.1 \underline{\mathrm{ab}}$ & $3.1 \underline{\mathrm{a}}$ & $12.4 \underline{\mathrm{a}}$ & 5 \\
11 & $149 \mathrm{a}$ & $11.7 \mathrm{~b}$ & $49.9 \underline{\mathrm{a}}$ & $104.5 \underline{\mathrm{a}}$ & $1.9 \mathrm{e}$ & $1.8 \mathrm{~d}$ & $3.5 \mathrm{c}$ & 2 \\
Media & 113 & 28.92 & 24.93 & 36.89 & 2.802 & 2.872 & 10.059 & 7
\end{tabular}

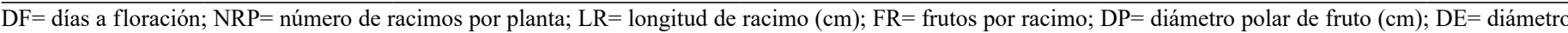

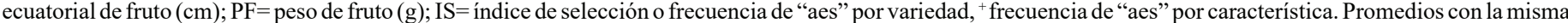
letra dentro de columnas son estadísticamente iguales según la prueba de Duncan $(p \leq 0.05)$. 


\section{Características de semillas}

Para variedades se detectó significancia para las siete características de semillas evaluadas (Cuadro 7). Hubo significancia en repeticiones en las variables volumen de semilla (VL) y peso de 100 semillas (PCS).
The variables that were correlated with REN: $\mathrm{AP}(r=0.82$, $p<0.01)$, NR $(r=0.70, p<0.05)$, LDS $(r=0.74, p<0.05)$ and $\operatorname{NRP}(r=0.79, p<0.01)$, other variables were also correlated positively. NRP/PCS, DP/PCS, DE/PCS, PF/ PCS and LS; AS and GS with PCS. negative correlations were found days to flowering; $\mathrm{DF} / \mathrm{NRP}(\mathrm{r}=-0.69, p<0.05)$;

Cuadro 7. Relaciones entre fuentes de variación y características de semillas en Montecillo; cuadrados medios y significancia, ciclo abril-diciembre de 2013.

Table 7. Relations between sources of variation and seed characteristics Montecillo; square means and significance, from april to december of 2013 cycle.

\begin{tabular}{ccccccccc}
\hline FV & GL & LS & AS & GS & VL & RLA & PCS & REN \\
\hline Repeticiones & 3 & $0.01 \mathrm{~ns}$ & $0.01 \mathrm{~ns}$ & $0.004 \mathrm{~ns}$ & $0.02 *$ & $0.0002 \mathrm{~ns}$ & $318.52^{*}$ & $47.50 \mathrm{~ns}$ \\
Variedades & 10 & $0.28^{* *}$ & $0.28^{* *}$ & $0.04^{* *}$ & $0.22^{* *}$ & $0.02 * *$ & $2024.51 * *$ & $90.78^{*}$ \\
CV & & 3.86 & 3.72 & 3.02 & 9.88 & 1.82 & 12.31 & 31.17 \\
$\mathrm{R}^{2}$ & & 0.92 & 0.96 & 0.94 & 0.89 & 0.96 & 0.84 & 0.64 \\
\hline
\end{tabular}

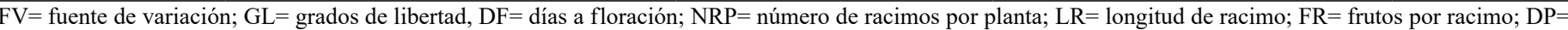

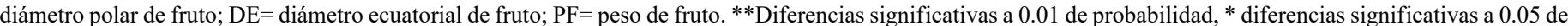
probabilidad $\mathrm{ns}=$ no significativo.

\section{Variación de las características de semillas e índice de selección entre variedades}

Las variedades 5(Riric10), 6(Riric19) y 10(Riric1) fueron las de mejor índice de selección con valores de 6 (Cuadro 8). Los resultados obtenidos para la variable peso de 100 semillas muestran una amplitud en las medias obtenidas para variedades que da una idea de la variabilidad que existe entre estos materiales cultivados. Ésta misma variabilidad fue observada en Morelos por Barrios et al. (2013). De la misma forma, Mazzani (1983), reporta resultados similares a esta investigación en Maracay, Venezuela encontrando peso de 100 semillas entre 19 y $91.8 \mathrm{~g}$.

Las variedades que tuvieron las mayores frecuencias en los índices de selección: V6 (Riric19), V2 (Riric 265-1) y V10 (Riric1) se conglomeraron en el grupo III del ACP con la diferencia que en las componentes principales las variables están confundidas y en los índices están explicitas (Figura3).

Las variables que más se correlacionaron con REN fueron: $\mathrm{AP}(\mathrm{r}=0.82, p<0.01), \mathrm{NR}(\mathrm{r}=0.70, p<0.05), \mathrm{LDS}(\mathrm{r}=0.74$, $p<0.05)$ y NRP $(\mathrm{r}=0.79, p<0.01)$, otras variables que también se correlacionaron positivamente fueron. NRP/PCS, DP/ PCS, DE/PCS, PF/PCS, así como LS; AS y GS con el PCS. Se encontraron correlaciones negativas en días a floración; $\mathrm{DF} /$ $\mathrm{NRP}(\mathrm{r}=-0.69, p<0.05) ; \mathrm{DF} / \mathrm{FR}(\mathrm{r}=0.84, p<0.01) ; \mathrm{DF} / \mathrm{PF}$
$\mathrm{DF} / \mathrm{FR}(\mathrm{r}=0.84, p<0.01) ; \mathrm{DF} / \mathrm{PF}(\mathrm{r}=-0.50, p<0.05) ; \mathrm{DF} /$ PCS $(\mathrm{r}=-0.69, p<0.05) ; \mathrm{DF} / \mathrm{REN}(\mathrm{r}=-0.54, p<0.05)$, $\mathrm{LR} / \mathrm{PF}(\mathrm{r}=-0.81, p<0.01), \mathrm{LR} / \mathrm{PCS}(\mathrm{r}=-0.84, p<0.01)$, $\mathrm{FR} / \mathrm{PF}(\mathrm{r}=-0.83, p<0.01)$ and FR/PCS $(\mathrm{r}=-0.91$, $p<0.01)$.

\section{Conclusions}

The variability was found in higuerilla varieties in terms of the morphological characteristics of the plant as well as features of clusters, especially fruits and seed size. This allowed us to differentiate groups which had different production potential, beating the unimproved variety CP13 used as a witness. Comparing with improved unimproved varieties included in this study, it follows that DT, NR, NH, LDS, bass and precocity (DF) flies are the characteristics of more emphasis on improving. The longer showed improved cluster and number of fruits per cluster that can be added to improved by breeding schemes. According to the best selection indices varieties V2 (RIRIC 265-1) Barranca Honda, Michoacan, V6 (Riric19) of Villa Corzo and V10 (Riric1) ofCacahoatán, Chiapas were the best adapted to the conditions of planting April Montecillo. However, the severe frost, seed production which suggests the possibility of generating 
$(\mathrm{r}=-0.50, p<0.05) ; \mathrm{DF} / \mathrm{PCS}(\mathrm{r}=-0.69, p<0.05) ; \mathrm{DF} / \mathrm{REN}(\mathrm{r}=$ $-0.54, p<0.05), \mathrm{LR} / \mathrm{PF}(\mathrm{r}=-0.81, p<0.01), \mathrm{LR} / \mathrm{PCS}(\mathrm{r}=-0.84, p<$ $0.01), \mathrm{FR} / \mathrm{PF}(\mathrm{r}=-0.83, p<0.01)$ y FR/PCS $(\mathrm{r}=-0.91, p<0.01)$ improved material adapted to this altitudinal level was achieved. The method of selection indexes used was efficient to clarify the best varieties and clearly informs

Cuadro 8. Comparación de medias de las características de semillas e IS de las variedades de higuerilla en Montecillo, ciclo abril-diciembre de 2013.

Table 8. Comparison of means of the characteristics of seeds and IS higuerilla varieties in Montecillo, cycle from april to december 2013.

\begin{tabular}{|c|c|c|c|c|c|c|c|c|}
\hline Variedades & $\mathrm{LS}(\mathrm{cm})$ & $\mathrm{AS}(\mathrm{cm})$ & $\mathrm{GS}(\mathrm{cm})$ & $\mathrm{VL}(\mathrm{ml})$ & RLA & PCS (g) & $\operatorname{REN}\left(\mathrm{g} \mathrm{p}^{-1}\right)$ & IS \\
\hline 1 & $1.53 \mathrm{e}$ & $1.21 \mathrm{ed}$ & $0.73 \mathrm{~d}$ & $0.60 \mathrm{ef}$ & $1.27 \mathrm{~cd}$ & $60.28 \mathrm{~cd}$ & $1102 \underline{\mathrm{a}}$ & 1 \\
\hline 2 & $1.86 \underline{\mathrm{a} b}$ & $1.50 \underline{a b c}$ & $0.82 \mathrm{bc}$ & $0.93 \underline{a} \mathrm{~b}$ & $1.24 \mathrm{def}$ & $88.22 \underline{\mathrm{a}}$ & $663 \mathrm{~b}$ & 4 \\
\hline 3 & $1.81 \mathrm{bc}$ & $1.50 \mathrm{bc}$ & $0.83 \mathrm{bc}$ & $0.85 \underline{a b c}$ & $1.20 \mathrm{f}$ & $83.96 \underline{\mathrm{ab}}$ & $585 \mathrm{~b}$ & 2 \\
\hline 4 & $1.74 \mathrm{~cd}$ & $1.44 \mathrm{c}$ & $0.81 \mathrm{c}$ & $0.78 \mathrm{~cd}$ & $1.21 \mathrm{f}$ & $73.25 \mathrm{bc}$ & $868 \underline{a b}$ & 1 \\
\hline 5 & $1.95 \underline{\mathrm{a}}$ & $1.58 \underline{\mathrm{a}}$ & $0.85 \underline{\mathrm{a}} \mathrm{b}$ & $0.93 \underline{a b}$ & $1.23 \mathrm{ef}$ & $93.88 \underline{\mathrm{a}}$ & $771 \underline{\mathrm{a} b}$ & 6 \\
\hline 6 & $1.96 \underline{\mathrm{a}}$ & $1.57 \underline{\mathrm{ab}}$ & $0.86 \underline{\mathrm{ab}}$ & $0.95 \underline{\mathrm{a}}$ & $1.25 \mathrm{cde}$ & $93.25 \underline{\mathrm{a}}$ & $794 \underline{\mathrm{ab}}$ & 6 \\
\hline 7 & $1.69 \overline{\mathrm{d}}$ & $1.26 \mathrm{~d}$ & $0.74 \mathrm{~d}$ & $0.67 \mathrm{de}$ & $1.34 \mathrm{~b}$ & $67.88 \mathrm{~cd}$ & $801 \underline{\mathrm{a} b}$ & 1 \\
\hline 8 & $1.77 \mathrm{bcd}$ & $1.44 \mathrm{c}$ & $0.80 \mathrm{c}$ & $0.82 \mathrm{bc}$ & $1.23 \mathrm{ef}$ & $82.38 \underline{\mathrm{ab}}$ & $1106 \underline{\mathrm{a}}$ & 2 \\
\hline 9 & $1.36 \mathrm{f}$ & $1.16 \mathrm{e}$ & $0.71 \mathrm{~d}$ & $0.53 \mathrm{f}$ & $1.17 \mathrm{~g}$ & $54.80 \mathrm{~d}$ & $914 \underline{\mathrm{a} b}$ & 1 \\
\hline 10 & $1.96 \underline{\mathrm{a}}$ & $1.54 \underline{\mathrm{ab}}$ & $0.87 \underline{\mathrm{a}}$ & $0.91 \underline{a} b$ & $1.27 \mathrm{c}$ & $88.52 \underline{\mathrm{a}}$ & $767 \underline{a b}$ & 6 \\
\hline 11 & $1.21 \mathrm{~g}$ & $0.76 \mathrm{f}$ & $0.54 \mathrm{e}$ & $0.21 \mathrm{~g}$ & $1.60 \underline{\mathrm{a}}$ & $22.85 \mathrm{e}$ & $297 \mathrm{~b}$ & 1 \\
\hline Media & 1.71 & 1.36 & 0.78 & 0.74 & 1.27 & 73.57 & 787.85 & \\
\hline${ }^{+}$Frec-pc & 4 & 4 & 3 & 5 & 1 & 6 & 8 & \\
\hline
\end{tabular}

$\mathrm{LS}=$ longitud de semilla $(\mathrm{cm}) ; \mathrm{AS}=$ ancho de semilla $(\mathrm{cm}) ; \mathrm{GS}=$ grosor de semilla $(\mathrm{cm}) ; \mathrm{VL}=$ volumen de semilla $(\mathrm{ml}) ; \mathrm{RLA}=$ relación largo- ancho; PCS= peso de 100 semillas $(\mathrm{g})$; REN = rendimiento de semillas $\left(\mathrm{g} \mathrm{p}^{-1}\right)$; IS= índice de selección o frecuencia de "aes" por variedad, frecuencia de "aes" por característica, Promedios con la misma letra dentro de columnas son estadísticamente iguales según la prueba de Duncan $(p \leq 0.05)$.

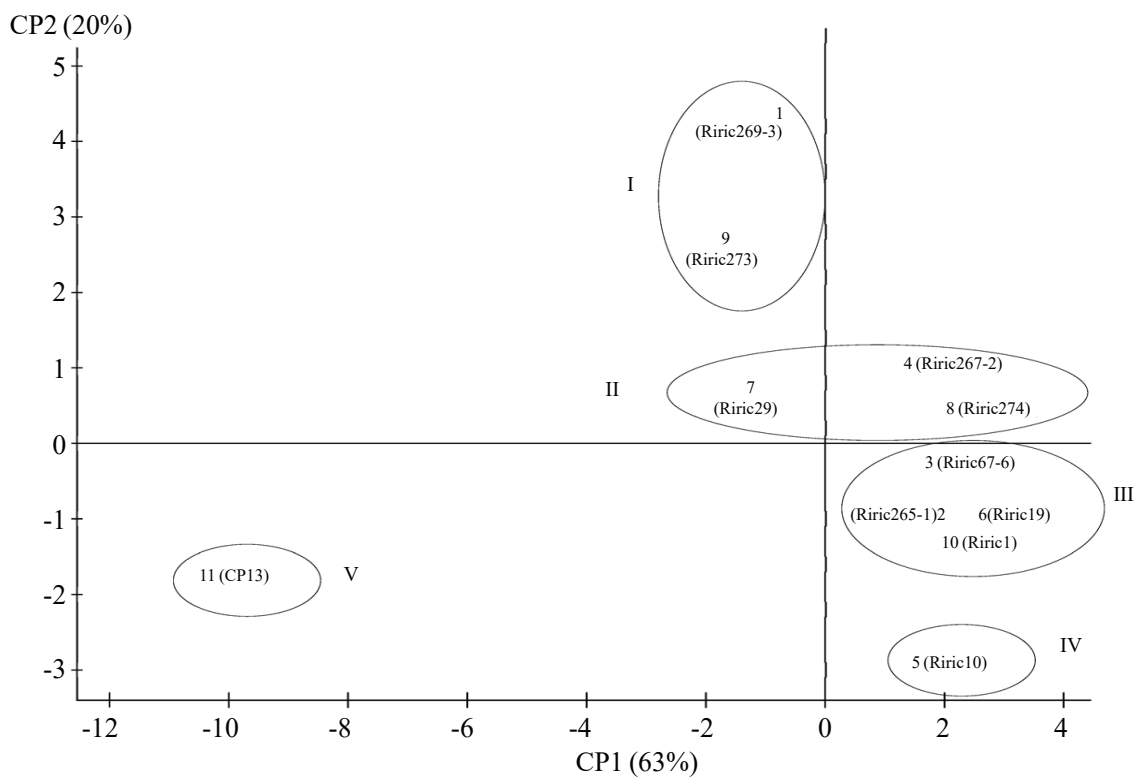

Figura 3. Distribución de las variedades de higuerilla en Montecillo, ciclo abril- diciembre de 2013: v1, v2, v3, v4, v5, v6, v7, v8, v9, v10 y v11.

Figure 3. Distribution of higuerilla varieties in Montecillo, cycle april- december 2013: v1,v2,v3,v4, v5, v6,v7,v8, v9, v10 and v11. 


\section{Conclusiones}

Se encontró variabilidad en las variedades de higuerilla, en cuanto a las características morfológicas de planta así comoen los rasgos de racimos, frutos y sobre todo el tamaño de semilla. Esto permitió diferenciar grupos, los cuales presentaron diferentes potenciales de producción, superando a la variedad no mejorada CP13 utilizada como testigo. Al comparar las variedades mejoradas con la no mejorada incluida en este estudio, se infiere que DT, NR, NH, LDS, porte bajo y precocidad (DF) son las características de más énfasis en el mejoramiento. La no mejorada mostró mayor longitud de racimo y número de frutos por racimo que pueden agregarse a las mejoradas mediante esquemas de mejoramiento. De acuerdo a los mejores índices de selección las variedades $\mathrm{V} 2$ (Riric 265-1) de Barranca Honda, Michoacán, V6 (Riric19) de Villa Corzo y V10 (Riric1) de Cacahoatán, Chiapas fueron las de mejor adaptación a las condiciones de siembra de abril en Montecillo. No obstante, de las heladas severas, se logró producción de semilla lo que sugiere la posibilidad de generar material mejorado adaptado a este nivel altitudinal. El método de índices de selección utilizado fue eficiente para precisar las mejores variedades e informa claramente las características que determinan el índice lo que permite dirigir mejor el mejoramiento y concordó con los agrupamientos determinados por componentes principales.

\section{Agradecimientos}

AlColegio de Postgraduados en Ciencias Agrícolas, por las facilidades otorgadas para esta investigación, al Instituto Nacional de Investigaciones Forestales, Agrícolas y Pecuarias (INIFAP), por su interés y apoyo a la capacitación y actualización del personal investigador, así como al Consejo Nacional de Ciencia y Tecnología (CONACYT) por la beca de postgrado otorgada.

\section{Literatura citada}

Barrios, G. E.; Zamarripa, C.A.; Canul, K. J.; Hernández,A. M.;Alarcón, C. N. y Chepetla, C. V.H. 2013. Evaluación de materiales elite de higuerilla en Morelos. Ciencia y Tecnología Agroprecuaria. 1(2):27-32.

Brigham, R. D. 1993. Castor: return of an old crop. In: Janick, J. and Simon, J. E. (Eds.) New crops. John Wiley \& Sons, New York. 380-383. the characteristics that determine the index allowing the improvement and better target agreed with the groups determined by major components.

\section{End of the English version}

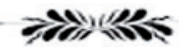

Egli, D. B.; Wiralaga, R. A. and Ramseur, E. L. 1987. Variation in seed size in soybean. Agron. J. 79:463-467.

Fanan, S.; Medina, P. F. and Camargo, M. B. P. 2009. Description of agronomic characteristics and harvest time evaluation in the yield of castor bean cultivar IAC 2028. Bragantia. 68:415-422.

FAOSTAT. 2011. Dirección de Estadística. http://faostat3.fao.org/ home/S.

García, E. 2005. Modificación al Sistema de Clasificación Climática de Köppen. $4^{\mathrm{a}}$ (Ed.). Universidad Nacional Autónoma de México (UNAM). México, D. F. 217 p.

Hay, F. R.; Smith, R. D.; Ellis, R. H. and Butler, L. H. 2010. Developmental changes in the germinability, desiccation tolerance, hardseededness, and longevity of individual seeds of Trifolium ambiguum. Ann. Bot. 105:1035-1052.

Kumar, P. V.; Ramakrishna, Y. S.; Rao, B. V. R.; Victor, U. S.; Srivastava, N.N. and Rao,A.V.M.S. 1997. Influence of moisture, thermal and photoperiodic regimes on the productivity of castor beans (Ricinus communis L.). Agric. Forest Meteorol. 88:279-289.

Lima, J. R. S.; Dantas, A. A. C.; Soares, S. E.; Brayner, O. L. C. A. and Da-Silva, I. F. 2013. Seasonal and interannual variations of evapotranspiration, energyexchange, yield and water use efficiency of castor grown underrainfed conditions in northeastern Brazil. Industrial Crops and Products. (50):203211

Machado, C. G.; Martins, C. C.; Silva, L. B. and Cruz, S. C. C. 2009. Production and physical characteristics of castor bean seeds affected by raceme and fruit position. Acta Scientiarum. Agronomy. (31):293-299.

Martínez, V. B. B.; Hernández, C. M.; Solís, B. J. L. and Zamarripa, C. A. 2012. Calidad agroindustrial del aceite de higuerilla (Ricinus communis L.) para la producción de bioenergéticos en México. In: V Congresso Brasileiro de Mamona / II Simpósio Internacional de Oleaginosas Energéticas \& I Fórum Capixaba de Pinhão Manso, Guarapari (ES). 2 p.

Mazzani, B. 1983. Cultivo y mejoramiento de plantas oleaginosas. Caracas, Venezuela: Fondo Nacional de Investigaciones Agropecuarias. 277-360 p.

Moshkin, V.A. and Alekseev, A. P. 1986. Ripening of seeds. In: Moshkin, V.A. (Ed.). Castor. New Delhi, Amerind. 315 p.

Purseglove, J. W. 1974. Tropical Crops. Dicotyledons. London, (Longman). $519 \mathrm{p}$.

Rajala,A.; Mäkelä, P.; Muurinen, S. and Peltonen-Sainio, P. 2009. Spring wheat response to timing of water deficit through sink and grain filling capacity. Field Crops Res. 114:263-271.

Rzedowski, G. C. y Rzedowski, J. 2001. Flora fanerogámica del Valle de México. 2a (Ed.). Instituto de Ecología y Comisión Nacional para el Conocimiento y Uso de la Biodiversidad. Pátzcuaro, Michoacán, México. 1406 p.

Sailaja, M.; Tarakeswari, M. and Sujatha, M. 2008. Stable genetic transformation of castor (Ricinus communis L.) via particle gun-mediated gene transfer using embry oaxes from mature seeds. Plant Cell Rep. 27:1509-1519. 
Sadras, V. O. and Slafer, G. A. 2012. Environmental modulation of yield components in cereals: Heritabilities reveal a hierarchy of phenotypic plasticities. Field Crops Res. 127:215-224.

Sarwar, G. and Boota, C. M. 2008. Evaluation of castor (Ricinus communis L.) induced mutants for possible selection in the improvement of seed yield. Span. J. Agric. Res. 6(4):629-634.

Sepúlveda, G. I. 2012. Bioturbosina. Producción de cultivos energéticos para la aviación comercial. Rev. Mex. Cienc. Agríc. 3(3):579594.

Severino, L. S. 2012. Studies on yield components and seed physiology of castor (Ricinus communis L.). Adissertation in plant and soil science. Texas Tech University. $117 \mathrm{p}$.

Soratto, R. P.; Souza-Schlick, G. D.; Giacomo, B. M. S.; Zanotto, M. D. and Fernandes, A. M. 2011. Low-height castor bean row spacing and plant population for mechanical harvest. Pesquisa Agropecuária Brasileira. 46:245-253.

Scholz, V.E. y Da-Silva, N. J. 2007. Óleo de mamona como combustível: fatos, perspectivas e riscos. Engenharia na Agricultura, Viçosa, M. G. 15(2):168-172.

Stachetti, R. G.; Aparecida, R. I.; Almeida, B. C. C.; Viera, L. M. A.; Moreno, P. A. M.; Frighetto, R. T. S. and Irias, L. J. M.2007. Socio-environmental impact of biodiesel production in Brazil J. Technol. Manag. Innov. 2(2):46-66.
Tobar, H. J. R. 1981. Evaluación de tres densidades de siembra en variedades guatemaltecas e híbridos sur africanos del cultivo de higuerillo (Ricinus communis L.). Tesis profesional. Universidad de San Carlos de Guatemala. Facultad de Agronomía. Guatemala. 152 p.

Vavilov, N. I. 1992. Origin and geography of cultivated plants. Traslated by D. Löve. Cambridge: Cambridge University Press. 498 pp.

Vibrans, H. Modificado de Mondragón P. J. (2004) 2009. Malezas de México, Ficha Ricinus communis.http://www.conabio.gob. $\mathrm{mx} / \mathrm{malezasdemexico/euphorbiaceae/ricinus-communis/}$ fichas/pagina1.htm.

Weiss, E. A. 1983. Oilseed Crops (book). Longman, London. 660 p.

Zamarripa, C. A.; Solís, B. J. L.; Martínez, V. B. B. y Cotoc, B. J. C. 2010. Evaluación y selección de materiales elite de higuerilla (Ricinus communis L.), para la obtención de biocombustibles en México. In: Memoria V Reunión Nacional de Innovación Agrícola, INIFAP. 245 p.

Zamarripa, C. A.; Solís, B. J. L.; Riegelhaupt, E. M.; Martínez, V. B. B. y Hernández, C. M. 2012. Balance de emisiones de gases de efecto invernadero del cultivo de higuerilla en la producción de biodiesel en México. In: V Congresso Brasileiro de Mamona/II Simpósio Internacional de Oleaginosas Energéticas \& I Fórum Capixaba de Pinhão Manso, Guarapari (ES). 1 p. 